\title{
A study of the effects of company size on systematic risk based on the capital asset pricing model among accepted companies in Tehran Stock Market
}

\author{
Payman Akbari $^{\mathbf{a}^{*}}$, Reza Rostami ${ }^{\mathrm{b}}$ and Akbar Veismoradi
}

\author{
${ }^{a}$ Master of Commercial Management, Young Researchers Club, Kermanshah Branch, Islamic Azad University, Kermanshah, Iran \\ ${ }^{b}$ Department of Management, Payam Noor University Harsin, Kermanshah, Iran \\ ${ }^{c}$ Department of Management, Payam Noor University Harsin, Kermanshah, Iran

ARTICLEINFO ABSTRACT

Article history:

Received December 18, 2011

Received in Revised form

February, 20, 2011

Accepted 28 March 2012

Available online

April 32012

\section{Keywords:}

Market value of stocks

Book value of stocks

Level of company sale

Trade volume of stocks

Price dividend ratio

Systematic risk (Beta)

\begin{abstract}
Systematic risk (beta) is one of the most effective factors in predicting the appropriate required rate of return of portfolios. Understanding systematic risk of usual portfolio of various companies helps investors consider financial investment, more confidentially. The aim of this study is to determine if there is any significant relationship between Company Size (Market value of stocks, Book value of stocks, level of company sale, trade volume of stocks, Price dividend ratio) as independent variables and Systematic risk (Beta) as dependent variables. The study chooses 112 companies accepted in Tehran Stock Market based on screening (systematic deletion) in a six-year- period from 2005 to 2010 . The required data were gathered from basic financial statement, committee reports, and other available documents in Tehran Stock Market. Regression and Pearson correlation were used to analyze the data. The results of the study revealed that there is a significant relationship between the variables. Some suggestions regarding the topic of the research are given too.
\end{abstract}

(C) 2012 Growing Science Ltd. All rights reserved.

\section{Introduction}

One of the primary objectives of any investment is to gain profit (Jnani \& Hadi Zadeh, 2001). Profit or return of portfolios includes current income (annual income) and increase or decrease of assets value. The real rate of return of investment in financial resources shows the previous performance of investors (Shabahang, 2008). There are many ways for investment in each financial marketplace based on the scope of the market. Investors invest their capital according to rate of return and assets risk (Yahyazadeh \& Khoramdin, 2008; Allen \& Bujang, 2009). Therefore, they seek some precise instruments to calculate adequately projects as well as firms to become quite sure in predicting the appropriate required rate of return of portfolios (Sterada \& Sera, 2006, 221-243). Investors' society gave special attention to idea of risk during 1950s to 1960s; however, there were not any particular measuring criteria for this concept.

* Corresponding author.

E-mail addresses: peymanakbari3537@yahoo.com (P. Akbari) 
A model for selecting an optimum investment portfolio devised by Markowitz (Rayeli \& Brawn, 2007, p 50). It uses a discrete-time, continuous-outcome approach for modeling investment problems, often called the mean-variance paradigm. Later, he proposed Markowitz efficient frontier. $\mathrm{He}$ believed that the graphical depiction of the Markowitz efficient set of portfolios representing the boundary of the set of feasible portfolios that have the maximum return for a given level of risk. Any portfolios above the frontier cannot be achieved. Markowitz efficient portfolios (Dastgir \& Bazazzadeh, 2007, Markowitz, 1959) dominate any below the frontier. After Markowitz's model, many theories and models regarding capital asset pricing were presented including the model proposed by William Sharpe. Sharpe independently developed a heretical notion of investment risk and reward, a sophisticated reasoning that has become known as the capital asset pricing model (CAPM). CAPM is used to determine a theoretically appropriate required rate of return of an asset. The model takes into account the asset's sensitivity to non-diversifiable risk, which is also known as systematic risk or market risk. It is normally represented by the quantity beta $(\beta)$ in the financial industry, as well as the expected return of the market and the expected return of a theoretical risk-free asset. However, the review of literature presents a variety of predicting rate of return and assets risk models which are not predictable through CAPM (Aghabigi, 2005; Reilly\& Brown, 2011).

In asset pricing and portfolio management the Fama-French three factor model is designed to describe stock returns (Fama \& French, 1992-3). The traditional asset pricing model, known formally as the CAPM, uses only one variable, beta, to describe the returns of a portfolio or stock with the returns of the market as a whole. In contrast, the Fama-French model uses three variables. Fama and French started with the observation that two classes of stocks have tended to do better than the market as a whole: (i) small caps and (ii) stocks with a high book-to-market ratio (BtM, customarily called value stocks, contrasted with growth stocks). They then added two factors to CAPM to reflect a portfolio's exposure to these two classes (Fama \& French, 1993, p3-56).

$$
r=R_{f}+\beta\left(K_{m}-R_{f}\right)+b_{s} S M B+b_{v} H M L+\alpha,
$$

where $r$ is the portfolio's rate of return, $R_{f}$ is the risk-free return rate, and $K_{m}$ is the return of the whole stock market. The "three factor" $\beta$ is analogous to the classical $\beta$ but not equal to it, since there are two additional factors to do some of the work. SMB stands for "small (market capitalization) minus big" and HML for "high (book-to-market ratio) minus low"; they measure the historic excess returns of small caps over big caps and of value stocks over growth stocks. These factors are calculated with combinations of portfolios composed by ranked stocks (BtM ranking, Cap ranking) and available historical market data. Historical values may be accessed on Kenneth French's web page.

Moreover, once SMB and HML are defined, the corresponding coefficients $b_{s}$ and $b_{v}$ are determined by linear regressions and can take negative values as well as positive values. (Fama \& French, 1992, p427-465). The Fama-French three factor model is a method used by finance professionals to explain the risk and return of equity portfolios. The three factor model compares a portfolio to three distinct risks found in the equity market to assist in decomposing returns. Gene Fama and Ken French found that on average, a portfolio's beta explains about 70\% of its actual returns. They design a more elaborate model that uses three risk factors. In the Fama-French three factor model, beta is still the most important risk factor because it still accounts for $70 \%$ of the typical diversified portfolio return however the size of the stocks in a portfolio and the price-to-book value of the stocks made significant differences.

Size is the second risk factor in the three-factor model, where it compares the weighted average market value of the stocks in a portfolio to the weighted average market value of stocks on the 
market. The third factor compares the amount of value stock exposure in relation to the market. Value stocks are companies that tend to have lower earnings growth rates, higher dividends, and higher book value compared to price (BtM). Fama-French measured the performance of high BtM stocks (value stocks) against low BtM stock (growth stocks) and found that these two styles act very differently. In the long run, value stocks have generated higher returns than growth stocks, albeit because value stocks have higher risk ${ }^{1}$. As it was mentioned above the main purpose of investors in investing in stock markets is to gain more profits. To do so, they want to invest somewhere with the highest rate of return of portfolios and the least risk of losing their funds. In order to sustain their funds and gain more profits these investors need to scrutinize factors affecting these markets under different economical situations. Factors such as company size and $\mathrm{P} / \mathrm{E}$ ratio over return or systematic risk of companies stocks determine the investor's decision when he/she intends to buy some stocks. Moreover, they can compare small and big size companies and enjoy higher degree of confidence if they consider the impact of those two factors. In other words, understanding systematic risk of usual portfolio of various companies, investors consider financial investment more confidentially (Mosavi kashi, 1999, p3).

Determining the company size and systematic risk can pave the way for making decision in investment. Thus, the main purpose of this study is to identify a suitable criterion for determining the amount of return of investment and stock risk in accepted companies in Tehran Stock Markets. This research tries to explore the relation between company size variable and systematic risk based on the CAPM model. Furthermore, the study tries to disclose this idea whether the information about company size can be considered as a criterion for assessing the amount of systematic risk in accepted companies in Tehran Stock Markets. According to CAPM, beta is the mere determining factor for the rate of return of investment. Hence, understanding the relationship among company size factors (Market value of stocks, Book value of stocks, level of company sale, trade volume of stocks) and Price dividend ratio with systematic risk can help investors and stock market brokers determine the risk of companies' stocks.

The main research question is as follows:

Is there a significant relationship between company size and systematic risk based on CAPM accepted companies in Tehran stock markets?

The effect of these factors and proving the relationship among them can help investors tolerate less risk. Availability of sufficient information about company size and beta factor and ease of calculation encourage researchers to do more research in these areas. The outcome of this very study can help researchers theoretically and practically. The results of this study can help investor decide more wisely in investing their capitals in Tehran stock markets.

\section{Review of literature}

Jalilian (2011) studied the relationship between company size and systematic risk based on the CAPM on accepted companies in Tehran stock markets. Their study included 112 Tehran companies in stock market. The study covered the period of five years (2005-2009). The results revealed that there was a significant relationship between company size and systematic risk based on the CAPM in accepted companies in Tehran stock markets.

\footnotetext{
${ }^{1}$ ) If necessary, interested researchers can see the following article of under site: www.w3.org, Fama-French Three Factor Model: Low cost investment manager, Portfolio Solutions
} 
Gorjizadeh (2010) studied the relationship between systematic risk and benefit growth of accepted companies in Tehran stock markets. He proposed three hypotheses and chose 114 firms from accepted companies in Tehran stock markets for the period of six year from (2001) to (2007). He calculated the variables of margin gross growth, operating benefit growth, net profit growth, and systematic risk. The results revealed that there was a significant relationship between systematic risk and benefit increase of accepted companies in Tehran stock markets.

Masihe et al. (2010) estimated systematic risk in different periods and utilized wavelet method in newly established Persian Gulf stock markets. Seven Persian Gulf stock markets were analyzed from 2007 to 2008. The result of the study showed that there was a significant difference in beta average coefficient in countries member in GCC. This issue was in accordance to various theoretical expectations of stock market investors in different periods. This difference was the result of various business strategies.

Alan and Bojang (2009) investigated the beta stability as systematic beta index using CAPM. Their study included 50 Malaysian companies member in stock market. The study covered the period of seven years from January 1994 to December 2001. The result indicated that two models of Fama and French and CAPM explain negative and positive increase of financial resources and occasionally revenue. However, the results of these models are dramatically different.

Vaez et al. (2008) investigated the possibility of predicting stocks price in Tehran stock markets using CAPM. The researcher selected companies in non-metal mineral industries, brokers and car industries. These companies were active from 1999 to 2003. The results disclosed that the impact of stock value is associated with stock intrinsic valve, which was impractical during the study period.

Chariton and Constantinidis (2004) studied the size and book-to-market factors in earning and returns department of business administration. The results indicated that if the market factor alone used in the capital asset pricing model, $\mathrm{R}^{2}$ of the model would be between 60 to 93 percent, but if added the company's size and $\mathrm{BE} / \mathrm{ME}$ factors, $\mathrm{R}^{2}$ will be 84 to 97 percent, which means that multi-factor model is better than single-factor model.

Ahmadpour (2000) studied the effects of operating leverage, financial leverage, company size on systematic risk of accepted companies in Tehran stock markets. The results revealed that there was a significant relationship between financial leverage, company size and systematic risk. However, no significant relationships between operating leverage, sale and systematic risk were found.

\section{Research questions and hypotheses}

The aim of the present study is to investigate any significant relationship between company sizes (Market value of stocks, Book value of stocks, level of company sale, and trade volume of stocks) and ratio of price on benefit as an independent variable and systematic risk of usual portfolio as a dependent variable. The study includes one main hypothesis and five minor hypotheses. If necessary, the impact of research variables in two forms will be investigated. In the first case inflation index and wholesale price index and adjustment services will be considered while in the second case service adjustment will not be included in the study. 
The main hypothesis states that there is a significant relationship between company size and systematic risk based on the capital asset pricing model.

The other research hypotheses are as follows

1) There is a significant relationship between market value of stocks and systematic risk based on the capital asset pricing model.

2) There is a significant relationship between book value of stocks and systematic risk based on the capital asset pricing model.

3) There is a significant relationship between level of company sale and systematic risk based on the capital asset pricing model.

4) There is a significant relationship between trade volume of stocks and systematic risk based on the capital asset pricing model.

5) There is a significant relationship between price to earning per share ratio $\mathrm{P} / \mathrm{E}$ and systematic risk based on the capital asset pricing model.

Table 1 is devoted for a brief descriptions of different variables including market value and book value of stocks, sales level, trade volume, $\mathrm{P} / \mathrm{E}$ ratio and systematic risk.

\section{Table 1}

Theoretical \& Operational Definition of Project variables

\begin{tabular}{|c|c|c|c|}
\hline Name of variable & Kind of variable & Theoretical Definition & Operational Definition \\
\hline Market Value of stocks & Independent & $\begin{array}{l}\text { The price at which a security is trading and } \\
\text { could presumably be purchased or sold. What } \\
\text { investors believe a firm is worth; calculated by } \\
\text { multiplying the number of shares outstanding } \\
\text { by the current market price of a firm's shares. }\end{array}$ & $\begin{array}{l}\text { Number of stocks *the latest price of } \\
\text { the stocks }\end{array}$ \\
\hline Book value of stocks & Independent & $\begin{array}{l}\text { The book value of a stock is the value of its } \\
\text { total assets less total liabilities. Any balance } \\
\text { sheet is divided in } 3 \text { sections: Assets, Liabilities } \\
\text { and Shareholders Equity. Since Asset minus } \\
\text { Liability always equals Equity, getting the book } \\
\text { value of the stock is as simple as reading off the } \\
\text { value on the Total Equity line. }\end{array}$ & $\begin{array}{c}\text { Book value of stocks = Total } \\
\text { shareholders' equity - Stock benefit / } \\
\text { Number of stocks }\end{array}$ \\
\hline Level of company sale & Independent & \multicolumn{2}{|c|}{$\begin{array}{l}\text { Annual company sale is one of the main indexes to determine the performance of the } \\
\text { company }\end{array}$} \\
\hline Trade volume of stocks & Independent & \multicolumn{2}{|c|}{$\begin{array}{l}\text { The measure how many trades take place for a security or on an exchange on a given } \\
\text { trading day? A high trading volume is an indicator of a high level of interest in a security } \\
\text { at its current price. }\end{array}$} \\
\hline P/E Ratio & Independent & $\begin{array}{l}\text { The price of a security per share at a given time } \\
\text { divided by its annual earnings per share. Often, } \\
\text { the earnings used are trailing } 12 \text { month } \\
\text { earnings, but some analysts use other forms. } \\
\text { The P/E ratio is a way to help determine a } \\
\text { security's stock valuation, that is, the fair value } \\
\text { of a stock in a perfect market. It is also a } \\
\text { measure of expected, but not realized, growth. }\end{array}$ & $\begin{array}{c}\text { Daily price of stock/the benefit of each } \\
\text { stock }\end{array}$ \\
\hline Systematic Risk Beta & Dependent & $\begin{array}{l}\text { Also called undiversifiable risk or market risk. } \\
\text { A good example of a systematic risk is market } \\
\text { risk. The degree to which the stock moves with } \\
\text { the overall market is called the systematic risk } \\
\text { and denoted as beta. Systematic risk, also called } \\
\text { market risk, is risk that's characteristic of an } \\
\text { entire market, a specific asset class, or a } \\
\text { portfolio invested in that asset class }\end{array}$ & $=\operatorname{Cov}\left(R_{i}, R_{m}\right)$ \\
\hline
\end{tabular}




\section{Research Methodology}

This research is an applied research. According to the types of variables the research is descriptive in which the relationship among variables will be explored using regression and correlation coefficient equations. Research procedure includes all accepted companies in Tehran Stock Markets. The related data for testing the hypothesis will be collected from Tehran Stock Markets, annual data sheets, explanatory remarks of accepted companies in Tehran Stock Markets (including data sheet, benefit and lost) board of managers' reports and software showing financial information of companies. The study covers the period of six years. The collected data from Tehran Stock Market will be saved in data bank software such as Excel (field study). Pearson correlation will be used to find any relationship among the variables. Moreover, to assess the impact of each variable on dependent variable step wise regression analysis will be applied. The least square with confidence level of $95 \%$, $R^{2}$ coefficient, normalized $\bar{R}^{2}$ and $\mathrm{P}$ size is used. If $\mathrm{P}$-value $<5 \%$, then directional hypothesis approved otherwise the null hypothesis is approved. SPSS and Excel software's will be applied for presenting statistical graphs, tables, modeling and analysis of data. The statistical sample of this study will include all companies accepted in Tehran stock markets. Sample size will be selected according to the four following criteria and systematic deletion rule based on screening financial lists:

1. The financial lists data will be available for the period of Seven years (2005-2010).

2. The financial year for each 12 months period had been determined.

3. The under study companies be active at least for the last six months.

4. The under study companies are not investment companies.

Note that brokers and investing companies have not been considered in this study. Table 2 shows summary of the results for our investigations.

Table 2

The summary of statistical observations for different hypothesis

\begin{tabular}{cccccccc}
\hline $\begin{array}{c}\text { Type of } \\
\text { adjustments }\end{array}$ & $\begin{array}{c}\text { Hypothesis } \\
\text { Verification }\end{array}$ & $\mathrm{R}^{2}$ & $\mathrm{R}$ & $\mathrm{N}$ & $\mathrm{Sig}$ & $\begin{array}{c}\text { Std. } \\
\text { Error }\end{array}$ & P-value \\
\hline wholesale & $\mathrm{H}_{0}$ & 0.015 & 0.122 & 112 & 0.095 & 0.05 & 0.200 \\
price index & $\mathrm{H}_{1}$ & 0.043 & 0.207 & 112 & 0.095 & 0.05 & 0.028 \\
& $\mathrm{H}_{0}$ & 0.055 & -0.093 & 112 & 0.095 & 0.05 & 0.329 \\
& $\mathrm{H}_{1}$ & 0.009 & 0.235 & 112 & 0.095 & 0.05 & 0.013 \\
& $\mathrm{H}_{0}$ & 0.001 & -0.034 & 112 & 0.095 & 0.05 & 0.720 \\
\hline \multirow{2}{*}{ No } & $\mathrm{H}_{0}$ & 0.014 & 0.117 & 112 & 0.095 & 0.05 & 0.218 \\
adjustment & $\mathrm{H}_{1}$ & 0.038 & 0.194 & 112 & 0.095 & 0.05 & 0.041 \\
& $\mathrm{H}_{0}$ & 0.009 & -0.094 & 112 & 0.095 & 0.05 & 0.323 \\
& $\mathrm{H}_{1}$ & 0.009 & 0.218 & 112 & 0.095 & 0.05 & 0.021 \\
\hline Adjusting & $\mathrm{H}_{0}$ & 0.001 & -0.034 & 112 & 0.095 & 0.05 & 0.721 \\
for & $\mathrm{H}_{0}$ & 0.014 & 0.118 & 112 & 0.095 & 0.05 & 0.216 \\
inflation & $\mathrm{H}_{1}$ & 0.038 & 0.194 & 112 & 0.095 & 0.05 & 0.040 \\
& $\mathrm{H}_{0}$ & 0.009 & -0.093 & 112 & 0.095 & 0.05 & 0.328 \\
\hline & $\mathrm{H}_{1}$ & 0.052 & 0.229 & 112 & 0.095 & 0.05 & 0.015 \\
\hline
\end{tabular}


In addition, Table 3 demonstrates the results of our stepwise regression tests for different indexes.

Table 3

The results of stepwise regression analysis for the main hypothesis

\begin{tabular}{ccccccccccc}
\hline $\begin{array}{c}\text { Hypothesis } \\
\text { Verification }\end{array}$ & & Steps & $\mathrm{N}$ & $\mathrm{Sig}$ & $\begin{array}{c}\text {-value } \\
\mathrm{P}\end{array}$ & $\begin{array}{c}\text { Std. } \\
\text { Error }\end{array}$ & $\mathrm{F}$ & $\bar{R}^{2}$ & $\mathrm{R}^{2}$ & $\mathrm{R}$ \\
\hline $\mathrm{H}_{1}$ & Wholesale & 1 & 112 & 0.095 & 0.013 & 0.05 & 6.428 & 0.047 & 0.055 & 0.235 \\
$\mathrm{H}_{1}$ & price & 2 & 112 & 0.095 & 0.002 & 0.05 & 6.425 & 0.089 & 0.105 & 0.325 \\
$\mathrm{H}_{1}$ & index & 3 & 112 & 0.095 & 0.001 & 0.05 & 5.884 & 0.117 & 0.140 & 0.375 \\
\hline $\mathrm{H} 1$ & No & 1 & 112 & 0.095 & 0.021 & 0.05 & 5.487 & 0.039 & 0.048 & 0.218 \\
$\mathrm{H} 1$ & adjustment & 2 & 112 & 0.095 & 0.003 & 0.05 & 6.111 & 0.084 & 0.101 & 0.318 \\
$\mathrm{H} 1$ & & 3 & 112 & 0.095 & 0.001 & 0.05 & 5.563 & 0.110 & 0.134 & 0.366 \\
\hline $\mathrm{H} 1$ & Adjusting & 1 & 112 & 0.095 & 0.015 & 0.05 & 6.111 & 0.044 & 0.053 & 0.229 \\
$\mathrm{H} 1$ & $\begin{array}{c}\text { for } \\
\text { inflation }\end{array}$ & 2 & 112 & 0.095 & 0.003 & 0.05 & 5.962 & 0.082 & 0.099 & 0.314 \\
\hline
\end{tabular}

\subsection{The research results}

\subsubsection{Results of testing hypothesize}

1. There is a significant relationship between market value of stocks and systematic risk based on the CAPM model. The results of testing first hypothesis calculated by three measures presented in research are as follows,

Wholesale price index of goods and services, without adjustment and inflation rate, indicates that according to significant level of $0.200,0.218$ and 0.216 and acceptable error level $(5 \%)$ and confidence level of $95 \%$, do not have a meaningful relationship together. In other words, $\mathrm{H}_{0}$ hypothesis is acceptable and the hypothesis expresses that there is not meaningful relationship.

2. There is a significant relationship between book value of stocks and systematic risk based on the CAPM model. The results of testing the second hypothesis that are calculated by three measures presented in research as follows,

Wholesale price index of goods and services, without adjustment and inflation rate, indicates that according to significant level of $0.028,0.041$ and 0.040 and acceptable error level $(5 \%)$ and confidence level of $95 \%$, have meaningful relationships together. In other words, $\mathrm{H}_{1}$ hypothesis is acceptable, which means that there is meaningful relationship.

3. There is a significant relationship between level of company sale and systematic risk based on the CAPM model. The results of testing the third hypothesis that are calculated by three measures presented in research as follows,

Wholesale price index of goods and services, without adjustment and inflation rate, indicates that according to significant level of $0.329,0.323$ and 0.328 and acceptable error level $(5 \%)$ and confidence level of $95 \%$, do not represent a meaningful relationship together. In other words, $\mathrm{H}_{0}$ hypothesis is acceptable, which expresses that there is not any meaningful relationship. 
4. There is a significant relationship between trade volume of stocks and systematic risk based on the CAPM. The results of testing the fourth hypothesis, which are calculated by three measures presented in research as follows,

Wholesale price index of goods and services, without adjustment and inflation rate, indicates that according to significant level of $0.013,0.021$ and 0.015 and acceptable error level $(5 \%)$ and confidence level of $95 \%$, do represent a meaningful relationship together. In other words, $\mathrm{H}_{1}$ hypothesis is acceptable, which means that there is meaningful relationship.

5. There is a significant relationship between price to earnings per share ratio $\mathrm{P} / \mathrm{E}$ and systematic risk based on the capital asset pricing model. The results of testing the fifth hypothesis, which are calculated by three measures presented in research are as follows,

Wholesale price index of goods and services, without adjustment and inflation rate, indicates that according to significant level of $0.720,0.721$ and 0.720 and acceptable error level $(5 \%)$ and confidence level of $95 \%$, do not have a meaningful relationship together. In other words, $\mathrm{H}_{0}$ hypothesis is acceptable and this hypothesis expresses that there is not meaningful relationship.

The main hypothesis states that there is a significant relationship between company size and systematic risk based on the CAPM model. The results of testing the main hypothesis calculated by three measures presented in research as follows,

Wholesale price index of goods and services, without adjustment and inflation rate, which is briefly described as follows:

Wholesale price index, is done through three steps, in the first steps trade volume of stocks' variable is entered into the equation because it has the most influence, other variables are eliminated because they do not have meaningful impact. In this case, the amount of multiple $\mathrm{R}$ for trade volume of stocks is equal to 0.235 , which shows that this variable can predict 0.235 systematic risks when the added variables of level of company sale and book value of stocks predictive value will be 0.325 and 0.375 , respectively.

No adjustment is performed through three steps, in first steps trade volume of stocks variable is entered into the equation because it has the most influence, other variables are eliminated because they do not have meaningful impact. In this case, the amount of multiple $\mathrm{R}$ for trade volume of stocks is equal to 0.218 , which shows that this variable can predict 0.218 systematic risks and if the variables of level of company sale and book value of stocks predictive value will be 0.318 and 0.366 , respectively.

Adjusting by inflation rate, is executed through several steps, in first steps trade volume of stocks variable is entered into the equation because it has the most influence, other variables are eliminated since they do not have meaningful impact. In this case, the amount of multiple $\mathrm{R}$ for trade volume of stocks is equal to 0.229 , which shows that this variable can predict 0.229 systematic risks if the added variable of level of company sale stocks predictive will be 0.314 , respectively.

\section{Conclusions}

Investors are normally interested in using as much information as possible for pricing securities to maximize the overall return of their basket. Risk measurement is the basis for financial decision 
making. Capital market researchers are always seeking for more improved tools and methods for the purpose of calculating risks associated with portfolio management. CAPM model is one of the methods considered by many capital market researchers, which states that the stock return is a function of systematic risk (beta coefficient). The objective of this research was to explain the relationship between company size and systematic risk. The results of research show that there is a meaningful relationship between company size and systematic risk. Therefore, we can suggest that investors, creditors and activists of stock market to consider systematic risk (beta) at the time of dealing stocks for the purpose of achieving more efficiency.

\section{Acknowledgment}

The authors would like to thank the TSE officials for providing the necessary data and information. The authors are grateful to comments and suggestions made by anonymous referees.

\section{References}

AhmadPour, A. (2000). A study of the effects of operating leverage, financial leverage, company size on systematic risk of accepted companies in Tehran Stock Markets. Unpublished DA thesis. Tarbiat Moddares, Iran (In Farsi).

Aghabigi, S. (2005). The study of market, company size and market value of stock, book value of stock. Unpublished MA thesis. Shahid Beheshti University. Iran (In Farsi).

Allen, D., \& Bujang, I. (2009). Conditional Beta CAPM and duration dependence tests. 18th world IMACS Congress, Cains, 13-17.

Chariton, A., \& Constantinidis, E. (2004). Size and book-to-market factors in earning and returns department of business administration. University of Cyprus, Working paper.

Dastgir, M., \& Bazazzadeh, H.R. (2007). The effect of market value of stock on systematic risk. Economic Research Journal, 17, 173-211(In Farsi).

Fama, E. F., \& French, K. R. (1992). The cross-section of expected stock returns. Journal of Finance, 47(2), 427-465.

Fama, E. F., \& French, K. R. (1993). Common risk factors in the returns on stocks and bonds. Journal of Financial Economics, 33(1), 3-56.

Gorjizadeh, D. (2010). The study of relationship between systematic risk and benefit growth of companies accepted in Tehran Stock Market. Research Journal. 7, 30-41 (In Farsi).

Jalilian (2011). A study of the effects of company size on systematic risk based on the capital asset pricing model among accepted companies in Tehran Stock Market. Unpublished MA thesis. Islamic Azad University, Kermanshah Branch. Iran (In Farsi).

Jnani, M., \& and Hadi Zadeh, H. (2001). The study of relation between prices to income over achieved return income. Economical Stock Journal, 50, 311-318.

Markowitz, H. (1959). Portfolio Selection. $2^{\text {nd }}$ ed., John Wiley \& Sons Inc., 3-27.

Masihe, M., Alzahrani, M., \& Al-titi, O. (2010). Systematic risk and time scales. International Review of Financial Analysis, 19, 10-18.

Mosavi Kashi, M. (1999). The effect of company size on return of investment rate in companies accepted in Tehran Stock Market. Unpublished MA thesis. Shahid Beheshti University. Iran.

Reilly, F. K., \& Brown, K.C. (2011). Investment Analysis and Portfolio Management. $2^{\text {nd }}$ ed., SouthWestern College Pub.

Shabahang, R. (2008). Financial Management. $11^{\text {th }}$ ed. First volume, Tehran. Special Accounting Research Center (In Farsi).

Sterada, M., \& Sera, F. (2006). Financial Structure and Financial Strategy. Iuomal of Financial Research, 307(1), 221-243. 
Vaez, M., Abzari, M., \& Jamali, S.J. (2008). The predictability of the price of Tehran Stock Market price using the capital asset pricing model. Mashhad. Knowledge and Development Journal Series, $15(23), 49$.

Yahyazadeh Far, M. \& Khoramdin, J. (2008). Factors effecting liquidity and risk of illiquidity of Tehran stock market. Accounting Journal, 15(53), 101-118 (In Farsi). 